
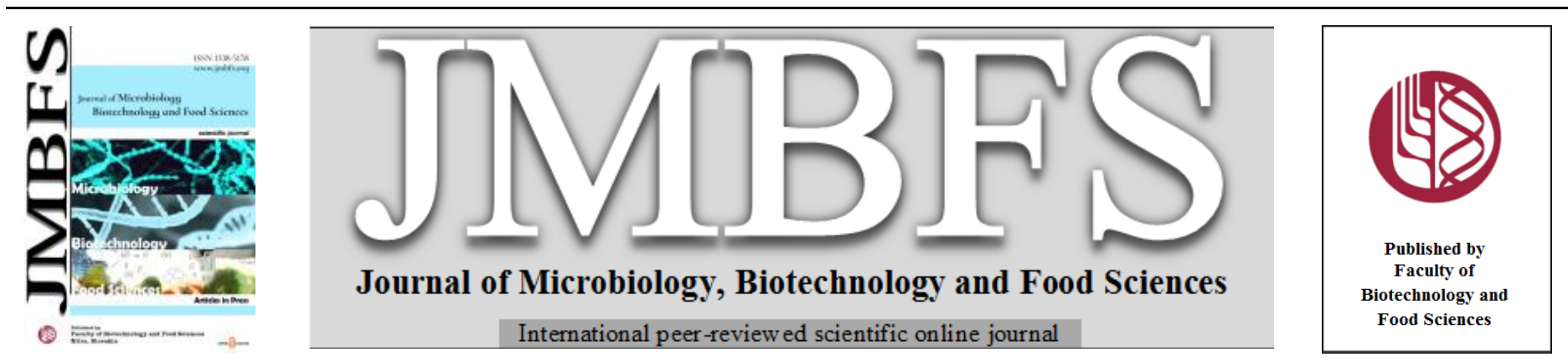

\title{
DEVELOPMENT AND CHARACTERIZATION OF PHYSICO-CHEMICAL AND FUNCTIONAL PROPERTIES OF GREEN TEA YOGHURT
}

\author{
Aparna Agarwal ${ }^{* 1}$, Manya Gupta ${ }^{1}$, Anjana Kumari ${ }^{1}$, Abhishek Gupta ${ }^{2}$ \\ Address(es): Dr. Aparna Agarwal, \\ ${ }^{1}$ Department of Food and Nutrition \& Food Technology, Lady Irwin College, Delhi University, Sikandra road, 110001, New Delhi. \\ ${ }^{2}$ Nestlé R \& D, Sector-8, Gurugram, 122050, Haryana, India.
}

\section{*Corresponding author: aparna.gupta@lic.du.ac.in}

\section{ARTICLE INFO}

Received 10. 4. 2021

Revised 20.11. 2021

Accepted 7. 12. 2021

Published 1. 4. 2022

Regular article

OPEN 2 ACCESS

\section{INTRODUCTION}

The Indian snacking market is booming and is expected to grow annually at a CAGR of 18\% (Bhattacharya 2019). This is due to increased emphasis on longterm wellness and health management and evolving consumer habits around traditional meals and snacking. The big dedicated meals have been replaced by snacks at frequent occasions. These snacks are expected to not only deliver pleasure, but also fulfil the physical and mental performance needs.

Amongst healthy snacks, yoghurts have gained high consumer acceptance owing to their easy digestibility and superior nutritional profile. They contain proteins of high biological value and are an excellent source of B-vitamins and minerals (calcium, phosphorus, magnesium, and zinc) (Mckinley et al. 2005). Yoghurts are commonly added with fruit, vegetable, or plant extracts (e.g. caffeine, guarana, green tea extract, coenzyme Q10, ginseng, aloe vera, cranberry, pomegranate pulp, flaxseed powder, and plant fibres) to enhance its nutritional benefits (NajgebauerLejko et al. 2014; Kumar et al. 2018). Tea infusion, in particular, is a promising ingredient since tea is widely consumed around the world. It has several functional benefits and has low $\mathrm{pH}$ of 4.2, which makes it easily compatible with yoghurts. Some reported health benefits of tea consumption are anticariogenic properties (Krahwinkel et al. 2000; Otake et al. 1991), improvement in bone density (Hegarty et al. 2000), weight loss (Dulloo et al. 1999), antibacterial effect against pathogens like Escherichia coli, Streptococcus salivarius, Clostridia, and Streptococcus mutans (Jeong et al. 2018), growth promotion of bifidobacteria and lactobacilli (Goto et al. 1998; Savard et al. 2011) and anti-stress/relaxation (Zhang et al. 2002). These benefits are mostly associated with the high polyphenol content of tea. Green tea is one of the most concentrated sources of polyphenols (30-45\% of its dry weight) (Vu et al. 2017; Sharma et al. 2007). Tea polyphenols are astringent and bitter and hence pose challenges in its application in yoghurts. Therefore, in many studies (Chatterjee et al. 2018; Muniandy et al. 2016; Amirdivani and Baba 2013), low levels of up to $2 \%$ (v/v) of tea infusion has been evaluated in the yoghurts. Most of these studies have been carried out in regions with high per capita green tea consumption, like Turkey (Çakmakci et al. 2019), Egypt (El-Ziney et al. 2017), Europe (Glibowski et al. 2019), China (Liu 2018), Malaysia and Iran (Amirdivani and Baba 2013). As a result, the acceptability of the green tea infused yoghurt by the consumers has been reasonably high. However, for other regions like India where black tea is predominantly consumed, it is therefore important to investigate the consumer acceptance of the green tea yoghurt. So far, only Chatterjee et al. 2018 has studied the development and sensorial acceptance of the green tea yoghurt amongst Indian consumers. Chatterjee et al. 2018 developed green tea yoghurt containing 2\% green tea, 3\% honey and $9 \%$ chocolate syrup. The acceptability of this green tea yoghurt was higher than the plain yoghurt, but the fermentation process was 14-16 hours long.
This was due to the use of mesophilic cultures and probably the green tea polyphenols in the yoghurt formulation. Such long fermentation times are industrially inefficient because of high energy utilization. Also, the risk of crosscontamination with yeasts, moulds, spoilage bacteria, and even pathogens may increase. Therefore, from the perspective of microbiological safety and industrial feasibility, a faster fermentation process (e.g. up to max. 4-5 hours) is desired Next, it is important to understand how the fermentation process gets impacted because of the addition of the green tea extract to milk.

The objective of our study was to develop the green tea yoghurt, study the physicochemical characteristics, and sensorial acceptance of green tea yoghurt amongst Indian consumers.

\section{MATERIAL AND METHODS}

\section{Ingredients}

Homogenized and pasteurized toned milk (3\% fat, $8.5 \%$ SNF, 3\% protein, Amul Taaza), milk powder ( $18 \%$ fat, $17 \%$ protein, Nestlé EveryDay), lemon and honey flavoured green tea (Twinings ${ }^{\mathrm{TM}}$ of London), sugar, pectin, and sun green colour containing tartrazine and brilliant blue FCF were purchased from local retail stores (Delhi, India). Freeze dried DVS Yoflex Express 1.0/30X50U containing Streptococcus salivarius subsp. thermophilus and Lactobacillus delbrueckii subsp. bulgaricus was kindly provided by DuPont India Pvt Ltd. (Gurgaon, India).

\section{Preparation of green tea yoghurt}

As per the Food Safety and Standards Authority of India (FSSAI, 2011), green tea yoghurt will be categorized as proprietary foods. In this category, there is no recommendation suggested for the composition of green tea yoghurts. Hence, as a guideline, the FSSAI standards for partly skimmed yoghurt (fat content of at least $0.5 \%(\mathrm{w} / \mathrm{v})$ but not more than $3.0 \%(\mathrm{w} / \mathrm{v})$ and a minimum of $3.0 \%$ protein $(\mathrm{w} / \mathrm{v})$ were followed. To comply with these requirements, $0.96 \%(w / v)$ and $0.97 \%(w / v)$ of milk powder was added to milk for the green tea and plain yoghurt formulations, respectively. The dry ingredients, i.e. sugar $(2 \% \mathrm{w} / \mathrm{v})$, milk powder, and pectin $(0.2 \% \mathrm{w} / \mathrm{v})$ were mixed together. This dry mix was added to the milk and continuously stirred using a mechanical agitator for $30 \mathrm{~min}$ at $60^{\circ} \mathrm{C}$ to ensure complete dissolution. The sun green colour Fast green FCF $(0.025 \% \mathrm{v} / \mathrm{v})$ and green tea leaves $(0.5 \%, 1 \%$, and $2 \% \mathrm{v} / \mathrm{v})$ were added to the standardized milk and heated for $15-20 \mathrm{~min}$ at $80-90{ }^{\circ} \mathrm{C}$ to maximize the extraction. This corresponded to the strength of a normal cup of tea. Subsequently, the tea leaves were strained out using a sterile kitchen sieve and the standardized green tea milk was cooled to $43^{\circ} \mathrm{C}$. The standardized green tea milk $(200 \mathrm{~mL})$ was inoculated with $0.15 \%(\mathrm{w} / \mathrm{v})$ of starter 
culture, mixed well, and poured into pre-sterilized high-density polyethylene cups. The cups were sealed and incubated at $43^{\circ} \mathrm{C}$ for 3 hours. After 3 hours, $\mathrm{pH}$ was measured, and the yoghurts were stored at $4-5^{\circ} \mathrm{C}$. The control yoghurt (without green tea extract) was prepared following the same process.

\section{Sensory analysis}

A panel of 10 members was trained for sensory evaluation following the procedures described by Folkenberg et al. 2006. A trained sensory panel of 10 members were asked to rank the yoghurts on different attributes on a scale of 1 to 9, with 1 being 'dislike extremely' and 9 being 'like extremely'. The yoghurt samples were evaluated based on colour, appearance, firmness, texture, flavour, mouthfeel, and overall acceptability.

\section{Shelf life evaluation}

All yoghurt samples were stored for 20 days at $4{ }^{\circ} \mathrm{C}$ till visible spoilage was observed. During storage, changes in appearance, colour, and aroma in yoghurts were recorded. The yoghurts were also analysed for total solids, $\mathrm{pH}$, ash, titratable acidity, protein, fat, antioxidant capacity, total phenolic content, and lactic acid bacteria (LAB) counts, yeast and mould, and coliform counts.

\section{Total solids/Moisture content}

The total solids content was determined according to the gravimetric method described in Indian standards 1479 (IS 1479 part II-1961). The moisture was calculated as 100 - \% total solids content.

\section{pH measurement}

The $\mathrm{pHs}$ of milks and yoghurts were analysed using a digital $\mathrm{pH}$ meter (Metroohm, India). The $\mathrm{pH}$ meter was calibrated using standard buffer solutions of $\mathrm{pH} 4,7$, and 10 .

\section{Ash content}

The ash content was measured using the gravimetric method (IS 1479 part II1961).

\section{Titratable acidity (\% lactic acid)}

The titratable acidity was determined using the standard method (IS 1166 (1986))

\section{Protein content}

The protein content was analysed following the Kjeldahl method (IS 1479 part II1961). The nitrogen to protein conversion factor used was 6.38 .

\section{Fat content}

The fat content of milk was analysed using the Gerber method (IS 1224 part II1977). And, for milk powder and yoghurts, the Rose Gottlieb method was used as described in IS 11721 (2013).

\section{Antioxidant activity}

The antioxidant activities of milk and yoghurt samples were analysed following the 1,1-diphenyl-2-picrylhydrazyl (DPPH) radical inhibition assay (Apostolidis $\boldsymbol{e t}$ al. 2007; Amirdivani and Baba 2015).

\section{Total phenolic content}

The total phenolic content (TPC) was determined as described by Shetty $\boldsymbol{e t}$ al . 2005. Briefly, the $\mathrm{pH}$ of the sample $(15 \mathrm{~g})$ was adjusted to 4.6 and then centrifuged $\left(4000 \mathrm{rpm}, 20^{\circ} \mathrm{C}\right)$. The supernatant obtained was filtered through $0.45 \mu \mathrm{m}$ filter and taken for analysis. To the filtrate $(1 \mathrm{~mL}), 1 \mathrm{~mL}$ of $95 \%$ ethanol and $5 \mathrm{~mL}$ of $\mathrm{dH}_{2} \mathrm{O}$ was added. Then, Folin-Ciocalteu reagent (diluted 1:1 with distilled water) was added to the sample followed by thorough mixing using a vortex mixer. To the reaction mixture, $1 \mathrm{~mL}$ of $\mathrm{Na}_{2} \mathrm{CO}_{3}(5 \%)$ was added and left to stand at room temperature for $1 \mathrm{~h}$. The absorbance was measured at $725 \mathrm{~nm}$ and converted to total phenolic content ( $\mu \mathrm{g}$ of Gallic acid equivalents (GAE)/mL of the sample). The calibration curves were prepared using different concentrations of gallic acid (5-60 $\mu \mathrm{g} \mathrm{GAE} / \mathrm{mL})$ in methanol.

\section{Microbiological analyses}

The total plate (IS 5402 (2012)), coliforms (IS 5401 part I (2002)), LAB (IS 12899:1989 (Reaffirmed 1999), and yeast and moulds (IS 5403:1999 (Reaffirmed 2005)) counts in yoghurts were determined according to the standard methods. Colony counts were expressed as colony forming units (cfu)/g.

\section{Data analyses}

All analyses were performed in duplicates. Averages and standard deviations were calculated for all data. Sensory evaluation scores were analysed using SPSS (version 24, SPSS Inc., Chicago, IL, USA). T-test and one-way analysis of variance (ANOVA) at 5\% significance were used to identify significant differences between the means.

\section{RESULTS AND DISCUSSION}

\section{Recipe optimization}

Toned milk (3\% fat, $3 \%$ protein), sugar, milk powder ( $18 \%$ fat, $17 \%$ protein), green tea extract, green colour, pectin, and starter culture were used to formulate the green tea yoghurt (Table 1).

Table 1 Formulations of green tea and plain yoghurts

\begin{tabular}{lcc}
\hline \multirow{2}{*}{ Ingredients } & Green tea yoghurt & Plain yoghurt \\
\cline { 2 - 3 } & \multicolumn{2}{c}{ Quantity $(\%)$} \\
\hline Toned milk & 95.60 & 96.99 \\
Sugar & 1.91 & 1.94 \\
Milk powder & 0.96 & 0.97 \\
Green tea extract & 0.96 & 0.00 \\
Green colour & 0.48 & 0.00 \\
Pectin & 0.10 & 0.10 \\
\hline Total & 100.00 & 100.00 \\
\hline
\end{tabular}

As expected, the green tea and the plain yoghurts had similar fat $(2.91 \%$ and $2.96 \%$ ) and protein contents (3.16\% and 3.00\%) (Table 2).

Table 2 Physico-chemical and microbiological characterization and antioxidant capacities of green tea and plain yoghurts

\begin{tabular}{lcc}
\hline $\begin{array}{l}\text { Physico-chemical } \\
\text { characterization }\end{array}$ & Green tea yoghurt & Plain yoghurt \\
\hline Total solids $(\%)$ & 15.75 & 14.20 \\
Fat $(\%)$ & 2.91 & 2.96 \\
Protein $(\%)$ & 3.16 & 3.00 \\
Ash $(\%)$ & 1.24 & 0.97 \\
pH & 4.65 & 3.38 \\
Acidity $(\%$ lactic acid) & 0.80 & 0.81 \\
\hline Microbiological analyses & & $2.6 * 10^{\wedge} 7$ \\
LAB (cfu/g) & $5.8 * 10^{\wedge} 7$ & not detected \\
Yeast and Mould (cfu/g) & not detected & \\
Coliforms (cfu/g) & not detected & 81.0 \\
\hline Antioxidant analyses & & \\
Total phenolics $(\mu \mathrm{g}$ & 397.9 & 49.7 \\
GAE/mL) & & \\
Antioxidant activity $(\%$ & 68.8 & not detected \\
inhibition of DPPH & & \\
oxidation) & & \\
\hline
\end{tabular}

* Average values are shown in the table. Coefficient of variation \% (Average/Standard deviation $* 100$ ) $<10 \%$ for all measurements

The yoghurts were made partly skimmed because consumers typically associate negatively with high fat products. It has been reported that consumers linked consumption of high fat products to elevated risks of hypertension, heart diseases, and strokes (Bus and Worsley 2003). Sensorially, on the other hand, consumers correlated positively the high fat content to rich mouthfeel and enhanced creaminess, viscosity, and body and texture of the products (Bus and Worsley 2003). In the absence of fat, the partly skimmed or low-fat yoghurts may exhibit sensory defects, like poor texture, low viscosity, increased syneresis, and dry and chalky mouthfeel (Lee and Lucey 2010). These defects may get enhanced even further by the astringent and bitter-tasting polyphenols present in the green tea extract (404 $\mu \mathrm{g}$ GAE/mL, Table 2). Cakmakci et al. (2019) reported that the green tea powder containing yoghurts received significantly lower sensory scores for odour, colour, and flavour as compared to the control plain yoghurt. Due to this reason, in several studies, green tea yoghurts have been prepared with low levels (1 or 2\%) of green tea extract (Jaziri et al. 2009; Yam et al. 1997; Çakmakci et al. 2019). Also, in this study, $0.5 \%, 1.0 \%$, and $2.0 \%(\mathrm{v} / \mathrm{v})$ of green tea extracts have been evaluated in the formulation (Fig. 1). From these formulations, the green tea yoghurt containing $1 \%(\mathrm{v} / \mathrm{v})$ extract had slightly higher acceptance than the yoghurts containing $0.5 \%$ and $2.0 \%(\mathrm{v} / \mathrm{v})$ extracts (Fig. 1). 
Sensory scores for yoghurts containing $0.5 \%, 1.0 \%$, and

9,0 $2.0 \%(v / v)$ green tea extracts

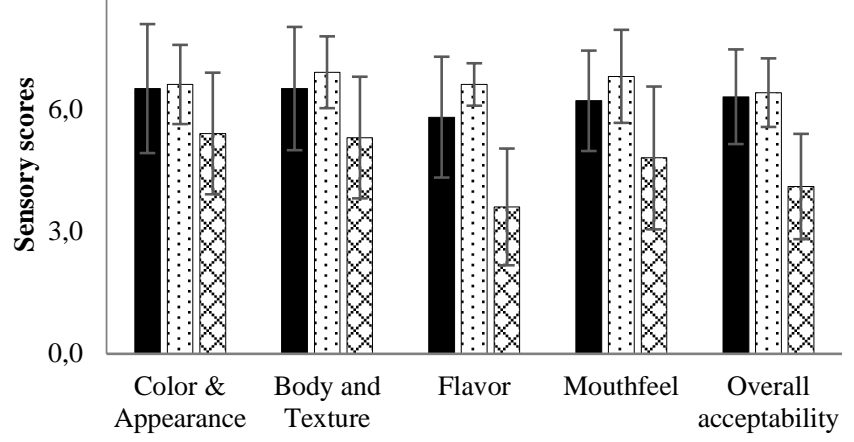

Figure 1 Sensory scores of yoghurts containing $0.5 \%(\boldsymbol{\square}), 1.0 \%$ (घ), and $2.0 \%$ $\mathrm{v} / \mathrm{v}(\boldsymbol{\otimes})$ of green tea extracts

Next to impact on sensory, addition of green tea extract resulted in syneresis and lower viscosity in the yoghurt. Similar findings have been reported by Amirdivani and Baba 2013. In that study, the apparent viscosities of the Malaysian green tea yoghurt (86.41 Pa.s) and Japanese green tea yoghurt (76.98 Pa.s) were much lower than that of the plain yoghurt (291.3 Pa.s) (Amirdivani and Baba 2013). Also, the syneresis increased in green tea yoghurts in a dose-dependent manner. This was attributed to the interference caused by green tea polyphenols in the yoghurt matrix (Jeong et al. 2018). Thus, to prevent loss in texture and prevent syneresis, pectin and carboxymethyl cellulose (CMC) were tested at $0.10 \%(\mathrm{w} / \mathrm{v})$ in yoghurt formulation. Pectin and $\mathrm{CMC}$ have been reported to be effective in the range of $\mathrm{pH}$ 4.0-4.6, decrease syneresis, and improve the mouthfeel and creaminess of yoghurts (Nguyen et al. 2017). It was observed that the yoghurts formulated with pectin $(0.1 \% \mathrm{w} / \mathrm{w})$ had better body and texture, lower syneresis, and had higher acceptability ( $\mathrm{p}<0.05$ ) as compared to the yoghurts formulated with CMC (data not shown). Pectin is generally perceived as a clean label ingredient, natural fibre, and is known for its prebiotic benefits (Chung et al. 2017; Khubber et al. 2021). $\mathrm{CMC}$, on the other hand, is perceived as an artificial, chemical-sounding, unnatura stabilizer (Cleaning up your labels, Accessed $15^{\text {th }}$ May 2021). Therefore, pectin was chosen for the green tea yoghurt formulation.

To determine the optimal sweetness, different sugar contents $(0 \%, 1 \%$, and $2 \%$ $\mathrm{w} / \mathrm{v})$ were tested in the formulation. The sugar addition improves the sensory profile and may partially mask the astringency and bitterness of green tea extract. It also contributes to the total solids content and improves the body and texture of the yoghurt. Sugar at $2 \% \mathrm{w} / \mathrm{v}$ was found to be most preferred based on the sensory evaluation of the three formulations (data not shown). This is interesting since the sugar level found optimal in this study is much lower than the optimal sugar content reported in other studies. Chatterjee et al. 2018 added 3\% honey in the green tea yoghurt. Additionally, approx. 5.7\% sugar was incorporated through addition of $9 \%(\mathrm{v} / \mathrm{v})$ of Hershey's chocolate syrup (containing $63.6 \%$ sugar). However, this was not taken into consideration. While higher sugar content improves the sensory profile, it may negate the potential health benefits (e.g. gut health, weight loss, and cholesterol lowering) offered by the green tea yoghurt. Using the optimized ingredient amounts as shown in Table 1, the green tea yoghurt was prepared and was evaluated with plain yoghurt as control using the consumer panel. The reproducibility of the sensory trials (five repeat trials) was rather high (coefficient of variation ranged between 1-5\%) for all the sensory attributes. This indicates the robustness of the experimental set up and the performed trials. The acceptability of the green tea yoghurt was marginally better than the plain yoghurt (Fig. 2).

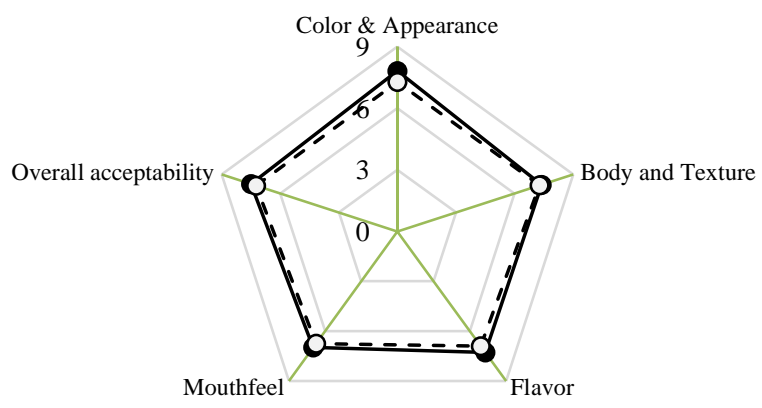

Figure 2 Sensory evaluation scores of green tea (- - ) and plain (---O---) yoghurts
The acceptability of the green tea yoghurt can be improved further by using bitterness masking natural flavours and increasing the sugar content to 4-5\% without compromising the nutritional/health benefits.

\section{Fermentation profile}

Based on the supplier (Danisco ${ }^{\mathrm{TM}}$ ) specifications, a thermophilic LB/ST starter culture was selected. The fermentation of the green tea yoghurt $(\mathrm{pH} 4.65)$ was much slower than that of the plain yoghurt (pH 3.38) (Fig. 3).

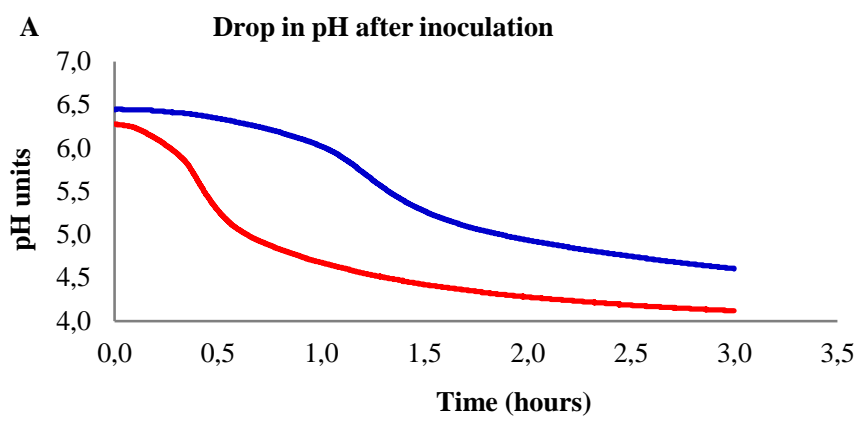

B

$\mathrm{pH}$ after 3 hours of inoculation

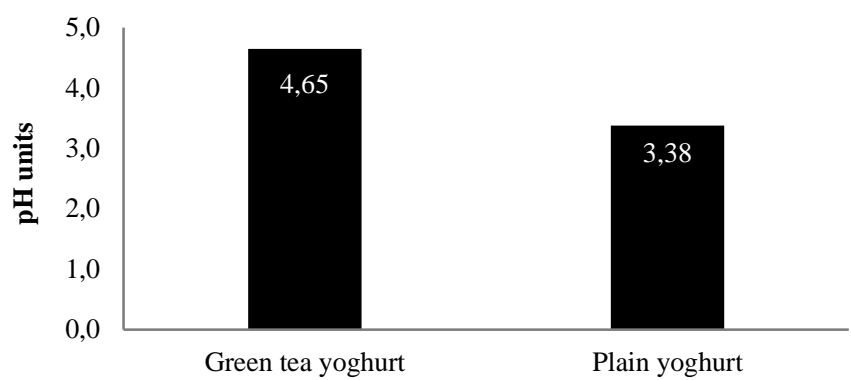

Figure 3 (A) Fermentation profiles of green tea (--) and plain (--) yoghurts and (B) $\mathrm{pH}$ after 3 hours of inoculation

Similar slowing down of the fermentation process due to addition of green tea extract has been reported earlier. The yoghurts containing $0 \%, 0.4 \%, 0.8 \%$, and $1.6 \%(\mathrm{v} / \mathrm{v})$ of green tea infusion had fermentation times of $4.11,5.10,7.30$, and 8.33 hours, respectively (Ochanda et al. 2015). However, in that study, the fermentation profiles were not shown. It is interesting to observe that the fermentation process of green tea yoghurt $(\mathrm{pH} 4.65)$ was slower than the plain yoghurt ( $\mathrm{pH} 3.38$ ) (Table 2 ), but the LAB count in green tea yoghurt $\left(5.8^{*} 107\right.$ cfu/g) was more than double of that measured in the plain yoghurt $\left(2.6^{*} 10^{7} \mathrm{cfu} / \mathrm{g}\right)$ Also, both the yoghurts had similar acidities of $\sim 0.81 \%$ lactic acid (Table 2). This suggests that the compounds present in the green tea extract exerted buffering action against the lowering of $\mathrm{pH}$ in the green tea yoghurt. Similar effects have been reported in previous research (Jeong et al. 2018). In contrast to slowing down, there are studies showing promotion (Amirdivani and Baba 2015 Alwazeer et al. 2020) and studies showing no effect of green tea extract addition (Jaziri et al. 2009) on the fermentation process. Hence, there is a need to understand the impact of green tea extract on the starter culture and the fermentation process.

\section{Antioxidant capacity of yoghurts}

The total phenolic contents of the green tea extract, plain yoghurt, and green tea yoghurt were 404, 81, and $398 \mu \mathrm{g} \mathrm{GAE} / \mathrm{mL}$, respectively (Table 2). Sigdel $\boldsymbol{e t}$ al . (2012) reported similar total phenolic content $(66.3 \mu \mathrm{g} \mathrm{GAE} / \mathrm{g})$ for plain yoghurt. On the other hand, as expected, significantly higher total phenolic contents of 479 $\mu \mathrm{g} \mathrm{GAE} / \mathrm{mL}$ and $319 \mu \mathrm{g} \mathrm{GAE} / \mathrm{mL}$ has been reported in green tea yoghurts by Muniandy et al. 2016 and Shokery et al. 2017, respectively.

There is a large variation in the reported total phenolic contents of the green tea extracts and the yoghurts between different studies. This variation is because of many reasons, like type and source of green tea, method of preparation of the extract, and dosages of green tea extract in the yoghurt. In the current study, $1 \%$ green tea extract corresponded to approx. $20 \mathrm{mg}$ of green tea powder added to the yoghurt (0.96 grams of green tea used for extraction; Assuming $2 \%$ of solids extracted from the green tea infusion; thus, $20 \mathrm{mg}$ of green tea powder/100 gram yoghurt). Even at this low level of supplementation, functional benefits of the green tea yoghurt may be expected. In a clinical study, 58 volunteers consumed Yoptimal $^{\mathrm{TM}}\left(10^{9} \mathrm{cfu} / 100\right.$ gram of BB-12 and LA-5 and $40 \mathrm{mg}$ of green tea extract) over a period of 4 weeks. At the end of that study, a significant increase in the faecal bifidobacteria and L. acidophilus was observed (Savard et al. 2011). This 
shows that the yoghurt containing green tea powder supported the growth of beneficial bacteria and suppressed pathogenic bacteria like Enterococci. Similar findings were reported by Goto et al. (1998), where administration of $300 \mathrm{mg}$ of tea catechins in long-term care patients significantly increased the bifidobacteria and lactobacilli and decreased the pathogenic bacteria, like bacteroids, eubacteria, enterobacteria, and clostridia. In addition to gut health improvement, other health benefits like weight loss and cholesterol management may be expected from green tea yoghurts. To establish the full spectrum of health benefits, additional clinical studies need to be undertaken.

\section{Changes during storage}

During storage $\left(4^{\circ} \mathrm{C}\right)$, minimal changes were observed in the moisture, ash, fat and protein contents of the yoghurts. There was an $11 \%$ and $13 \%$ decrease in the total phenolic content and the antioxidant activities of the yoghurts, respectively. This could be due to the degradation of phenolic compounds during storage. No coliform and yeast and mould growth were observed in the green tea and plain yoghurts suggesting hygienic production of the yoghurts. Also, the lactic acid bacteria count did not change over storage. However, the titratable acidity of the yoghurts increased from 0.72 to $1.0 \%$ lactic acid and the $\mathrm{pH}$ decreased from 4.65 to 3.47. Due to this rapid post-acidification, the sensory acceptance of the green tea yoghurt decreased during the storage. A detailed overview of the factors causing post-acidification and its control is reviewed in literature by Deshwal $\boldsymbol{e}$ al. 2021. In our study, the fermentation process needs to be further optimized by selecting thermophilic starter cultures with slower rate of post-acidification.

\section{CONCLUSION}

A sensorially acceptable green tea yoghurt was developed but there is a need to study the influence of green tea extract composition on the starter culture. This will help in optimizing the fermentation process and enhance the nutritive value of yoghurts. Some health benefits of the green tea yoghurts are already established, but it is necessary to investigate if these benefits can be enhanced further by the addition of functional ingredients like prebiotics.

\section{REFERENCES}

Alwazeer, D., Bulut, M., \& Tunçtürk, Y. (2019). Fortification of milk with plant extracts modifies the acidification and reducing capacities of yoghurt bacteria International Journal of Dairy Technology, 73(1), 117-125 http://doi:10.1111/1471-0307.12643

Amirdivani, S., \& Baba, A. S. (2013). Rheological properties and sensory characteristics of green tea yogurt during storage. Life Science Journal, 378-390. Amirdivani, S., \& Baba, A. S. H. (2014). Green tea yogurt: major phenolic compounds and microbial growth. Journal of Food Science and Technology, 52(7), 4652-4660. http://doi:10.1007/s13197-014-1670-6

Apostolidis, E., Kwon, Y.-I., \& Shetty, K. (2007). Inhibitory potential of herb, fruit, and fungal-enriched cheese against key enzymes linked to type 2 diabetes and hypertension. Innovative Food Science \& Emerging Technologies, 8(1), 4654. http://doi:10.1016/j.ifset.2006.06.001

Bhattacharya T. (2019) What's trending in Indian snacks, Mintel reports

Bus, A. E. M., \& Worsley, A. (2003). Consumers' sensory and nutritional perceptions of three types of milk. Public health nutrition, 6(2), 201-208. https://doi.org/10.1079/PHN2002417

Çakmakci S., Emel Ö. Z., Çakiroglu K., Polat A., Gülçin İ., Ilgaz Ş., Seyyedcheraghi K., Özhamamci İ. (2019) Probiotic shelf life, antioxidant, sensory, physical and chemical properties of yoghurts produced with Lactobacillus acidophilus and green tea powder. Kafkas Üniversitesi Veteriner Fakültesi Dergisi, (25).

Chatterjee, G., Das, S., Das, R. S., \& Des, A. B. (2018). Development of green tea infused chocolate yoghurt and evaluation of its nutritive value and storage stability. Progress in Nutrition, (20), 237-245. http://doi:10.23751/pn.v20i1 $\underline{\text { S.6081 }}$

Chung W. S. F., Meijerink M., Zeuner B., Holck J., Louis P., Meyer A. S., Wells J. M., Flint H. J. and Duncan S. H. (2017) Prebiotic potential of pectin and pectic oligosaccharides to promote anti-inflammatory commensal bacteria in the human colon. FEMS Microbiology Ecology, (93). https://doi.org/10.1093/femsec/fix127 Cleaning up your labels, Leverage the benefits of the industry's most enduring movement, https://emea.ingredion.com/solvechallenge/Clean_And_Simple/cleanlabel-ingredients.html, Accessed: 15th March (2021)

Deshwal, G. K., Tiwari, S., Kumar, A., Raman, R. K., \& Kadyan, S. (2021) Review on factors affecting and control of post-acidification in yoghurt and related products. Trends in Food Science \& Technology, 109, 499-512. https://doi.org/10.1016/j.tifs.2021.01.057

Dulloo A. G., Duret C., Rohrer D., Girardier L., Mensi N., Fathi M., Chantre P., and Vandermander J. (1999) Efficacy of a green tea extract rich in catechin polyphenols and caffeine in increasing 24-h energy expenditure and fat oxidation in humans. The American Journal of Clinical Nutrition, (70) 1040-1045 https://doi.org/10.1093/ajen/70.6.1040
El-Ziney M. G., Shokery E. S., Youssef A. H., and Mashaly R. E. (2017) Protective effects of green tea and moringa leave extracts and their bio-yoghurts against oxidative effects of lead acetate in albino rats. Journal of Nutritional Health and Food Science, (5), 1-11. http://dx.doi.org/10.15226/jnhfs.2017.00196

Folkenberg, D. M., Dejmek, P., Skriver, A., Guldager, H. S., and Ipsen, R. (2006) Sensory and rheological screening of exopolysaccharide producing strains of bacterial yoghurt cultures. International Dairy Journal, 16(2), 111-118 https://doi.org/10.1016/j.idairyj.2004.10.013

FSSAI. (2011). Food safety and standards (food products standards and food additives) Regulations (Vol. 4, p. 316). Part III, section https://fssai.gov.in/cms/food-safety-a nd-standards-regulations.php.

Glibowski, P., Karwowska, M., Latoch, A., Nosowska, K., \& Udeh, K. O. (2019)

Effect of different tea extracts on the physicochemical and sensory parameters of stirred probiotic yoghurts. Acta Scientiarum Polonorum Technologia Alimentaria, 18(2), 185-193. http://doi:10.17306/j.afs.0653

Goto, K., Kanaya, S., Ishigami, T., \& Hara, Y. (1999). Effects of Tea Polyphenols on Fecal Condetions, Part 2. The Effects of Tea Catechins on Fecal Conditions of Elderly Residents in a Long-Term Care Facility. Journal of Nutritional Science and Vitaminology, 45(1), 135-141. http://doi:10.3177/jnsv.45.135

Hegarty, V. M., May, H. M., \& Khaw, K.-T. (2000). Tea drinking and bone mineral density in older women. The American Journal of Clinical Nutrition, 71(4), 1003 1007. http://doi:10.1093/ajcn/71.4.1003

IS 1166 (1986) Specification for condensed milk, partly skimmed and skimmed condensed milk, Bureau of Indian Standards, Manak Bhavan, New Delhi

IS 1224 part II (1977) Determination of fat by the Gerber method-Part II: Milk products, Bureau of Indian Standards, Manak Bhavan, New Delhi

IS 1479 part II (1961) Methods of test for dairy industry-Part II: Chemical analysis of milk, Bureau of Indian Standards, Manak Bhavan, New Delhi

IS 5401 part I (2002) Microbiology-general guidance for the enumeration of coliforms

IS 5402 (2012) Microbiology of food and animal feeding stuffs-horizontal method for the enumeration of micro-organisms-colony-count technique at $30^{\circ} \mathrm{C}$

IS 5403:1999 (Reaffirmed 2005): Method for yeast and mould count of foodstuffs and animal feeds

IS 11721 (2013) Dried milk and dried milk products-determination of fat contentGravimetric method (reference) method, Bureau of Indian Standards, Manak Bhavan, New Delhi

IS 12899:1989 (Reaffirmed 1999): Dairy products-yoghurt, enumeration of specific lactic acid bacteria-method of test

Jaziri, I., Ben Slama, M., Mhadhbi, H., Urdaci, M. C., \& Hamdi, M. (2009). Effect of green and black teas (Camellia sinensis L.) on the characteristic microflora of yogurt during fermentation and refrigerated storage. Food Chemistry, 112(3), 614620. http://doi:10.1016/j.foodchem.2008.06.017

Jeong, C. H., Ryu, H., Zhang, T., Lee, C. H., Seo, H. G., \& Han, S. G. (2018) Green tea powder supplementation enhances fermentation and antioxidant activity of set-type yogurt. Food Science and Biotechnology, 27(5), 1419-1427 http://doi:10.1007/s10068-018-0370-9

Khubber, S., Chaturvedi, K., Thakur, N., Sharma, N., \& Yadav, S. K. (2021). Lowmethoxyl pectin stabilizes low-fat set yoghurt and improves their physicochemical properties, rheology, microstructure and sensory liking. Foo Hydrocolloids, (111), 106240. https://doi.org/10.1016/j.foodhyd.2020.106240

Krahwinkel, T., \& Willershausen, B. (2000). The effect of sugar-free green tea chew candies on the degree of inflammation of the gingiva. Eur J Med Res, 5(11), 463-7.

Kumar, S., Rasane, P., and Nimmanapalli, R. (2018). Optimisation of a process for production of pomegranate pulp and flaxseed powder fortified probiotic Greek dahi. International Journal of Dairy Technology, 71(3), 753-763. https://doi.org/10.1111/1471-0307.12494

Lee W. J. and Lucey J. A. (2010) Formation and physical properties of yoghurt. Asian-Australasian Journal of Animal Sciences, (23), 1127-1136.

Liu D. (2018) Effect of Fuzhuan brick-tea addition on the quality and antioxidan activity of skimmed set-type yoghurt. International Journal of Dairy Technology, (71), 22-33. https://doi.org/10.1111/1471-0307.12395

Mckinley M. C. (2005) The nutrition and health benefits of yoghurt. International Journal of Dairy Technology, (58), 1-12. https://doi.org/10.1111/j.1471 0307.2005.00180.x

Muniandy P., Shori A. B., and Baba A. S. (2016) Influence of green, white and black tea addition on the antioxidant activity of probiotic yoghurt during refrigerated storage. Food Packaging and Shelf Life, (8), 1-8 https://doi.org/10.1016/j.fpsl.2016.02.002

Najgebauer-Lejko D., Grega T., and Tabaszewska M. (2014) Yoghurts with addition of selected vegetables: acidity, antioxidant properties and sensory quality. Acta Scientiarum Polonorum Technologia Alimentaria, (13), 35-42 https://doi.org/10.17306/J.AFS.2014.1.3

Nguyen P. T., Kravchuk O., Bhandari B., and Prakash S. (2017) Effect of different hydrocolloids on texture, rheology, tribology and sensory perception of texture and mouthfeel of low-fat pot-set yoghurt. Food Hydrocolloids, (72), 90-104 https://doi.org/10.1016/j.foodhyd.2017.05.035

Ochanda S. O., Wanyoko J. K., Faraj A. K., Onyango C. A., and Ruto H. K. (2015) Effects of tea (Camellia sinensis) phytochemicals on the yoghurt cultures 
(Lactobacillus bulgaricus and Streptococcus thermophilus) during development and storage of tea fortified yoghurts. Journal of Food Research, (4), 59. http://doi:10.5539/jfr.v4n4p59

Otake S., Makimura M., Kuroki T., Nishihara, Y., and Hirasawa M. (1991) Anticaries effects of polyphenolic compounds from Japanese green tea. Caries Research, (25), 438-443. https://doi.org/10.1159/000261407

Savard P., Lamarche B., Paradis M. E., Thiboutot H., Laurin É., and Roy D. (2011) Impact of Bifidobacterium animalis subsp. lactis BB-12 and, Lactobacillus acidophilus LA-5-containing yoghurt, on faecal bacterial counts of healthy adults. International Journal of Food Microbiology, (149), 50-57. https://doi.org/10.1016/j.ijfoodmicro.2010.12.026

Sharma V. K., Bhattacharya A., Kumar A., and Sharma H. K. (2007) Health benefits of tea consumption. Tropical Journal of Pharmaceutical Research, (6), 785-792. http://doi:10.4314/tjpr.v6i3.14660

Shetty K., Vattem D. A., Clydesdale F. M., (2005) Clonal screening and sproutbased bioprocessing for phenolic phytochemicals for functional foods. In: Food biotechnology, 2nd edn, Shetty K., Paliyath G., Pometto A. L. III, Levin R. E. (eds), CRC press, Boca Raton

Shokery E. S., El-Ziney M. G., Yossef A. H., and Mashaly R. I. (2017) Effect of green tea and Moringa leave extracts fortification on the physicochemical, rheological, sensory and antioxidant properties of set-type yoghurt. Journal of Advances in Dairy Research, (5).

Sigdel, A., Ojha, P., and Karki, T. B. (2018). Phytochemicals and syneresis of osmo-dried mulberry incorporated yoghurt. Food science and nutrition, 6(4), 1045-1052. https://doi.org/10.1002/fsn3.645

Vu T., Mgebrishvili I., Hramova V., Korotkova A., and Gorlov I. (2017) The analysis of the using efficiency Japanese Matcha tea in the fermented milk products production. Journal of Hygienic Engineering and Design, (20), 86-91.

Yam T. S., Shah S., and Hamilton-Miller J. M. T. (1997) Microbiological activity of whole and fractionated crude extracts of tea (Camellia sinensis), and of tea components. FEMS Microbiology Letters, (152) 169-174 https://doi.org/10.1111/j.1574-6968.1997.tb10424.x

Zhang G., Miura Y., and Yagasaki K. (2002) Effects of dietary powdered green tea and theanine on tumour growth and endogenous hyperlipidemia in hepatomabearing rats. Bioscience, Biotechnology, and Biochemistry, (66), 711-716. https://doi.org/10.1271/bbb.66.711 